\title{
The Influence of Inquiry Learning Model on Student's Scientific Attitudes in Ecosystem Topic at MTs. Daarul Hikmah Sei Alim (Islamic Junior High School) Asahan
}

\author{
Haji Hamidun Sitorus ${ }^{1}$, Hasruddin ${ }^{1}$, Syahmi Edi ${ }^{1}$ \\ ${ }^{I}$ Department of Biology Education, Postgraduate Program, Universitas Negeri Medan, Jl. Willem Iskandar Psr \\ V Medan Estate-Indonesia (20221)
}

*Corresponding Author: Hasruddin, Department of Biology Education, Postgraduate Program, Universitas Negeri Medan, Jl. Willem Iskandar Psr V Medan Estate-Indonesia (20221)

\begin{abstract}
This study was conducted to determine the influence of Inquiry learning model on student's scientific attitudes in ecosystem material at MTs (islamic junior high school) Daarul Hikmah Sei Alim Asahan. The research method used was quasi experiment with 3 randomly determined classes sample taken by cluster random sampling technique. The research instrument used was a questionnaire of scientific attitudes related to the ecosystem. Data analysis technique used was Covariat Analysis at significant level $\alpha=$ 0.05 with the help of SPSS 22. The results showed there was significant influence of learning model on student's scientific attitude which taught by guided inquiry model (average 77.60), it significantly higher than modified free inquiry model (average 63.80) and conventional learning model (average 48.27). As a follow up, based on the results of this study, teachers expected to be able to apply guided inquiry model in ecosystem topics as an effort to improve student's scientific attitudes.
\end{abstract}

Keywords: Ecosystem, Inquiry, Scientific Attitudes.

\section{INTRODUCTION}

Inquiry-based learning refers to a pedagogical strategy that uses a general process of scientific inquiry as a teaching methodology and its learning. Scientific attitude in biology learning is reflected in the attitude and character of students in everyday life, therefore character education and scientific attitude in biology learning are closely related (Budur, 2013). This approach emphasizes student's inquiries, inquiries and problem solving similar to the processes used by scientists to conduct investigations and investigations in laboratories, on the field sites, in libraries, and in discussions with colleagues (Ketpichainarong, et al., 2010). In addition, Okada (2013) also stated a number of circles emphasize inquiry-based learning as an appropriate model of learning. This learning will further develop scientific mastery. This learning model aims to develop traditional learning that focused on memorizing into scientific understanding and skills.

This inquiry model in biology learning allows students to learn and do as scientists do. Students use the inquiry process to prove the problem and relate it to what they have learned (Jiun and Nurzatulshima, 2014). Students will be directed toward studying biological concepts and being able to take a scientific approach, combining abilities and empowering students. Students will play an active role in learning with teacher encouragement, with focused activities in solving problems. Inquiry learning model will also reduce the boring situation to the students when learning takes place (Opara, 2011). Puti and Jumadi (2014) stated that the inquiry motivates and encourages students to actively explore and master the subject matter themselves. Students will be able to be an active, independent and skilled person in solving problems and have a deep understanding of the concepts being studied. In addition, inquiry learning can arouse student's interest in learning, so students are motivated to continue learning in finding answers to the problems they find (Solichah et al., 2013).

Guided inquiry will be planned, targeted and constantly executed in accordance with the inquiry process. There is a model of information seeking process (ISP) as a student guide in guided inquiry based learning process. The ISP model describes thoughts, actions and feelings in seven stages: initiation, selection, exploration, formulation, presentations, collection, and assessment (Puspitasari, 2015). 
The main purpose of Guided inquiry is to develop independent students who know how to expand their knowledge and skills from various sources of information used both inside and outside the school, but teacher fully guides students in learning process (Riadi et al., 2015). In addition, Noviar and Madinah (2016) stated that inquiry can motivate and encourage students to actively master the subject matter themselves. Students will be able to be an active, independent and skilled person in solving problems and have a deep understanding of the concepts being studied.

Other learning models that can be applied in science learning activities as well as give a positive influence is Modified Free Inquiry learning model. This learning model requires students to plan research procedure or make steps in solving problem while teacher is only preparing the problem and providing the materials that students need. Furthermore, students are given considerable freedom to solve problems. The teacher asks questions that can help students understand the direction of problem solving, not explain what to do (Widiyaningsih, et al., 2012).

\section{Materials And Methods}

\subsection{Research Location, Population And Sample}

This research was conducted in MTs. Daarul Hikmah Sei Alim Hassak Village, Sei Dadap Subdistrict of Asahan Regency, Postal Code 21272. The study was conducted from February to April 2017 at the end of semester. Sample in this research was some member of target population which taken by using random sampling technique, three classes were choosen, class VII-1, as first experimental class which taught by Guided Inquiry model, class VII-2, as second experiment class which taught by Modified free Inquiry learning model and class VII-3, as a control class given conventional learning.

\subsection{Methods and Research Technique}

This research was quasi experimental research using method by conducting experiment in class which has been formed before without changing class situation and schedule of learning. The research design used in this research was pretest-postest experiment group design, therefore in its implementation used the first experimental group students and the second experimental group students. Scientific attitude was measured by using a scientific attitude questionnaire with a likert scale that had been modified in accordance with ecosystem material. Questionnaire of scientific attitudes consist of 30 questions with 5 options;SA (strongly agree), A (Agree), D (Doubtful), DA (disagree), and SDA (strongly disagree). Questionnaires scores ranged from 1 to 5 . Each answer option was given the following scoring weight: (1) for positive statements given 5 for SA, 4 score for A, 3 for D, 2 for DA, and 1 for the SDA; (2) for negative statements (rejects) given score 1 for SA, 2 score for A, 3 for D, 4 for DA, and 5 for SDA; (3) the highest ideal score calculation for 30 points of the questionnaire test was $30 \times 5=150$ and the ideal lowest score was $30 \times 1=30$.

\subsection{Data Analysis Technique}

Data analysis technique used in this study was decriptive analysis technique. Descriptive analysis techniques intended to describe the data research results. Testing hypothesis research by using Analysis of Covariate (Anacova) at level $\alpha=0,05$. If the statistical test results show a significant effect, then proceed with Tukey's test. Data processing using Statistical Package for Social Sciences (SPSS) version 22.

\section{RESEARCH RESULTS AND DISCUSSION}

\subsection{Research Results}

The pretest results (Table 1) showed that the student's initial ability in Guided Inkuiri (GI) model obtained the highest score of 65 and the lowest score 24 with an average score was $42.23 \pm 12.57$ and from the normality test using Kolmogorov- Smirnof test concluded that data of student's initial ability in Guided Inkuiri class was normally distributed $(0.52>0.05)$.In the class which was taught by Modified Free Inquiry (MFI) model, the highest score was 66 and the lowest was 25 with the mean score of $43.13 \pm 12.80$ and from the normality test using Kolmogorov-Smirnof test it was concluded that data of student's initial ability in Modified Free Inkuiri was normally distributed $(0.13>0.05)$. In conventional model (CONV) class obtained the highest score of 57 and the lowest score 24 with an average score of $41.33 \pm 11.79$ and from the normality test by using Kolmogorov-Smirnof test concluded that student's initial ability on Conventional class was normally distributed $(0.06>0.05)$. 
The Influence of Inquiry Learning Model on Student's Scientific Attitudes in Ecosystem Topic at MTs. Daarul Hikmah Sei Alim (Islamic Junior High School) Asahan

Postes results (Table 1) showed that student's ability in the class that was taught by Guided Inquiri (GI) learning model obtained the highest score of 88 and the lowest 65 with average and standard deviation of $77.60 \pm 7.37$. In the class that was taught by Modified Free Inquiry (MFI) model, the highest score was 82 and the lowest 54 was $54,80 \pm 7.88$. In the class taught by conventional learning model (KONV) obtained the highest score of 65 and the lowest was 32 with an average score was $48.27 \pm 12.21$.

Table 1. Student's Scientific attitudes Description

\begin{tabular}{|l|c|c|c|c|c|c|}
\hline \multirow{2}{*}{ Learning Model } & N & Min & Max & \multicolumn{2}{c|}{ Mean } & Std. Dev \\
\cline { 2 - 7 } & Statistic & Statistic & Statistic & Statistic & Std. Error & Statistic \\
\hline GI_Pretest & 30 & 24 & 65 & 44.23 & 2.294 & 12.566 \\
\hline GI_Posttest & 30 & 65 & 88 & 77.60 & 1.346 & 7.370 \\
\hline MFI_Pretest & 30 & 25 & 66 & 43.13 & 2.336 & 12.795 \\
\hline MFI_Posttest & 30 & 54 & 82 & 63.80 & 1.438 & 7.876 \\
\hline CONV_Pretest & 30 & 24 & 57 & 41.33 & 2.152 & 11.786 \\
\hline CONV_Posttest & 30 & 32 & 65 & 48.27 & 2.229 & 12.211 \\
\hline
\end{tabular}

Table 2. Normality Test of Student's Scientific attitudes Pretest

\begin{tabular}{|l|c|c|}
\hline \multirow{2}{*}{ Learning Model } & \multicolumn{2}{|c|}{ Kolmogorov - Smirnov } \\
\cline { 2 - 3 } GI_Pretest & Significance & Note \\
\hline MFI_Pretest & 0.052 & Normal \\
\hline CONV_Pretest & 0.131 & Normal \\
\hline
\end{tabular}

Covariate analysis resuts showed Guided Inquiry (GI), Modified Free Inquiry (MFI) and Convensional $(\mathrm{CONV})$ significance influence on student's scientific attitudes $(\mathrm{F}=73.019 ; \mathrm{P}=0.000)$. It means that Ha was accepted (Table 3).

Table 3. Anacove Result of Student's Science Attitude

\begin{tabular}{|c|c|c|c|}
\hline Variable & $\mathrm{F}_{\text {count }}$ & Significance & Note \\
\hline Science Attitude & 73.019 & 0.000 & Ha accepted \\
\hline
\end{tabular}

Research results showed that there was difference in posttes score of student's scientific attitude toward ecosystem material in MTs. Daarul Hikmah Asahan which taught by Guided Inquiry (GI) and Free Modified Inquiry (MFI) and conventional (CONV) models.

Tukey's test results for scientce attitudes showed that there was a significant difference in mean score between Guided Inquiry (GI), Modified Free Inquiry (MFI) and Conventional (CONV) models on student's science attitudes for science lesson about ecosystem topic in MTs (Junior high School) Daarul Hikmah Sei Alim Asahan (Table 4). While Tukey's test is to find the significant difference between Guided Inquiry (GI), Modified Free Inquiry and Conventional (CONV) models, showed significant difference in learning model (Table 5).

Table 4. Tukey's test of Science Attitudes dependent variable

\begin{tabular}{|l|l|c|c|c|}
\hline \multirow{2}{*}{ (I) FACTOR } & (J) FACTOR & Mean Difference (I-J) & Std. Error & \multicolumn{1}{l|}{ Sig. } \\
\hline \multirow{2}{*}{ GI } & MFI & $13.800^{*}$ & 2.429 & .000 \\
\cline { 2 - 5 } & KONV & $29.333^{*}$ & 2.429 & .000 \\
\hline \multirow{2}{*}{ MFI } & GI & $-13.800^{*}$ & 2.429 & .000 \\
\cline { 2 - 5 } & CONV & $15.533^{*}$ & 2.429 & .000 \\
\hline \multirow{2}{*}{ CONV } & GI & $-29.333^{*}$ & 2.429 & .000 \\
\cline { 2 - 5 } & MFI & $-15.533^{*}$ & 2.429 & .000 \\
\hline
\end{tabular}


The Influence of Inquiry Learning Model on Student's Scientific Attitudes in Ecosystem Topic at MTs. Daarul Hikmah Sei Alim (Islamic Junior High School) Asahan

Table 5. Tukey's test of Science Attitudes Posttest

\begin{tabular}{|l|c|c|c|c|}
\hline \multirow{2}{*}{ FACTOR } & \multirow{2}{*}{$\mathrm{N}$} & \multicolumn{3}{|c|}{ Subset for alpha $=0.05$} \\
\cline { 3 - 5 } & & 1 & 2 & 3 \\
\hline CONV & 30 & 48.27 & & \\
\hline MFI & 30 & & 63.80 & 77.60 \\
\hline GI & 30 & & & 1.000 \\
\hline Sig. & & 1.000 & 1.000 & \\
\hline
\end{tabular}

\subsection{Discussion}

The results of data processing indicate that there was a significant influence of the application of Guided Inquiry (GI), Modified Free Inquiry (MFI) and Conventional (CONV) models to the scientific attitudes of MTs (junior high school) students of Daarul Hikmah Sei Alim Asahan on science lesson about Ecosystem topics. Statistical analysis of Guided Inquiry model showed the highest average score $(77,60)$ compared to Modified Free Inquiry model $(63,80)$ and Conventional learning model $(48,27)$. Significant differences of learning models on student's scientific attitudes was shown best in Guided Inquiry learning model, this is in line with Natalina et al (2013) which also found the increase in student's scientific attitudes on the implementation of Guided Inquiry learning strategy in students of VIII7 SMPN 14 Pekanbaru. Furthermore, Dewi et al (2013) and Nursafiah et al (2015) from the results of hypothesis analysis showed that student's scientific attitudes which was taught by guided inquiry learning model is better than student's scientific attitudes which was taught by conventional learning model.

Other research conducted by Sutama et al (2014) also shows the influence of Inquiry learning model to student's scientific attitudes. Based on the average score obtained shows that the average score of scientific performance of students who follow inquiry learning is greater than the average score of scientific performance of students who follow other learning. This indicates that in the achievement of the scientific performance students who follow guided inquiry learning will give a positive influence (Nugroho, et al., 2012).

The significant influence of Guided Inquiry learning model on the increase of student's scientific attitudes in ecosystem topics, because in Guided Inquiry teacher can manage and implement a learning to students which contains scientific steps such as curiosity, ask questions which relevant to the material so students can answer questions asked by teachers well (Hayat and Yusuf 2012). This is in line with the results of research conducted Natalina et al (2013) which shows the Inquiry learning model can improve student's scientific attitudes characterized by the increasing average percentage of student'sscientific attitudes to indicators used such as: curiosity, cooperation and confidence. The same opinion was expressed by Margiastuti et al (2015) and Anggreini et al (2013) which stated that guided inquiry model is suitable to be applied in ecosystem learning material because students can know the environment directly. The inquiry learning model is one of the innovative learning models appropriately used in science learning, especially biology, in enhancing scientific attitudes, because it can develop student's ability to understand and acquire knowledge through systematic and scientific thinking (Boaventura and Faria, 2015). Inquiry focuses more on student activities in the learning process where students build knowledge and understanding of how a scientist works (Sutama, et al., 2014).

\section{CONCLUSiON}

There was a significant influence of the use of Guided Inquiry (GI), Modified Free Inquiry (MFI) and conventional (CONV) models on student's scientific attitudes in studying ecosystem in MTs. Daarul Hikmah Asahan. While the best result for student's scientific attitudes was obtained in the treatment of Guided Inquiry model compared to other learning model. Given the influence of Guided Inquiry learning model on the scientific attitudes of students in studying ecosystem, it is recommended for Madrasah Tsanawiah Daarul Hikmah Asahan to apply Guided Inquiry model to improve student's science attitude. 
The Influence of Inquiry Learning Model on Student's Scientific Attitudes in Ecosystem Topic at MTs. Daarul Hikmah Sei Alim (Islamic Junior High School) Asahan

\section{REFERENCES}

[1] Anggreini, W., P. Ristiati dan N.M. Widiyanti. 2013. Implementasi Strategi Pembelajaran Inquiry Terhadap Kemampuan Berpikir Kritis dan Pemahaman Konsep IPA Siswa SMP (implementation of Inquiry learning strategy on critical thinking skills and science concept understanding of junior high school students). e-Journal Program Pascasarjana Universitas Pendidikan Ganesha Program Studi IPA, (online) Volume 3, (htpp://www.undana.ac.id).

[2] Boaventura dan C. Faria, 2015. Science Inquiry-Based Activities in Elementary Education: How to Support Teacherse Practices. International Journal of Information and Education Technology. 5(6): 451 456.

[3] Budur, E. L. 2013. Integrasi Pendidikan Karakter Melalui Inkuiri dengan Lesson Studydalam Pembelajaran Biologi untuk Meningkatkan Sikap Ilmiah dan Hasil Belajar Kognitif Siswa Kelas VII SMPN I Singosari (integration of character education by inquiry with lesson study in biology learning to improve scientific attitudes and cognitive learning outcome of grade VII student's smpn 1 singosari) . Jurnal Pendidikan Sains, 1(2): 171 - 177.

[4] Dewi, N. L., N. Dantes, I. W. Sadia. 2013. Model Pembelajaran Inkuiri Terbimbing terhadap Sikap Ilmiah dan Hasil Belajar IPA (guided-inquiry learning model to science attitudes and science learning outcomes). Journal Program Pascasarjana Universitas Pendidikan Ganesha Jurusan Pendidikan Dasar. 1(3): 1-10.

[5] Hayat, B. dan S. Yusuf. 2012. Mutu Pendidikan (education quality). Jakarta: Bumi Aksara: 319 - 320.

[6] Jiun T. L. dan K. Nurzatulshima. 2014. Inquiry In Learning Science. International Journal of Technical Research and Applications: $61-65$.

[7] Ketpichainarong, W., B. Panijpan., P. Ruenwongsa. 2010. Enhanced learning of biotechnology students by an inquiry-based cellulase laboratory. International Journal of Environmental \& Science. 5(2):169 187.

[8] Margiastuti, N., Parmin., S. D. Pamelasari. 2015. Penerapan Model Guided Inquiry Terhadap Sikap Ilmiah dan Pemahaman Konsep Siswa pada Tema Ekosistem (Application of Guided Inquiry Model to Scientific Attitude and Understanding of Student Concept on Ecosystem Theme). Unnes Science Education Journal. 4(3): 141 - 148.

[9] Natalina, M., Y. Yusuf, Ermadianti. 2013. Penerapan Strategi Pembelajaran Inkuiri Terbimbing untuk Meningkatkan Sikap Ilmiah dan Hasil Belajar Biologi Siswa Kelas VIII-7 SMP Negeri 14 Pekanbaru, Tahun Ajaran 2012/2013 (Implementation of Guided Inquiry Learning Strategy to Improve Scientific Attitudes and biology learning outcomes of Student in Class VIII-7 SMP Negeri 14 Pekanbaru, School Year 2012/2013). Jurnal Biogenesis. 9(2): 28 - 38.

[10] Noviar, D. dan S. Madinah. 2016. Model Guided Inquiry Berbasis Scientific Approach dalam Pembelajaran IPA Biologi Siswa SMP (Scientific based-Guided Inquiry Approach in learning junior high biology science). Holistik Journal for Islamic Social Sciences. 1(1): 26 - 35

[11] Nugroho, S., Suparmi, Surwanto. 2012. Pembelajaran IPA dengan Metode Inkuiri Terbimbing Menggunakan Laboratorium Riil dan Virtuil Ditinjau dari Kemampuan Memori dan Gaya Belajar Siswa (science learning by guided inquiry using real and virtual laboratory viewed from memory skills and student's learning styles). Jurnal Inkuiri Pasca UNS, 3(1): 235 - 244.

[12] Nursafiah, C. Nurmaliah, H. Rahmatan. 2015. Penerapan Model Pembelajaran Inkuiri Terbimbing pada Materi Fotosintesis untuk Meningkatkan Sikap Ilmiah Peserta Didik di SMP Negeri 8 Banda Aceh (Implementation of Guided Inquiry Learning Model on Photosynthetic Material to Improve Student's Scientific Attitude in SMP Negeri 8 Banda Aceh). Jurnal Edu Bio Tropika. 3(1): 1 - 50.

[13] Okada, A. 2013. Scientific literacy in the digital age: tools, Environments and Sources for co-inquiry. European Scientific Journal, 4: 263 - 274.

[14] Opara J. 2011. Inquiry Method and Student Academic Achievement in Biology: Lessons and Policy Implications. American-Eurasian Journal of Scientific Research. 6 (1): 28 - 31.

[15] Puspitasari, A. D. 2015. Efektitas Pembelajaran Berbasis Guided Inquiry untuk Meningkatkan Literasi Sains Siswa (The Effectiveness of Guided Inquiry-Based Learning to Increase Student Science Literacy). Unnes Journal of Biology Education, 1(2): 1 - 5.

[16] Puti, S. dan Jumadi. 2014. Pengembangan Modul IPA SMP Berbasis Guided Inquiry untuk Menigkatkan Keterampilan Proses dan Sikap Ilmiah (Development of Guided Inquiry based-module to Improve Process Skills and Scientific Attitudes). Jurnal Pendidikan Matematika dan Sains,3(1): 80 - 85.

[17] Riyadi, I. P., B. A. Prayitno, Marjono. 2015. Penerapan Model Pembelajaran Inkuiri Terbimbing (Guided Inquiry) pada Materi Sistem Koordinasi untuk Meningkatkan Keterampilan Proses Sains pada Siswa Kelas XI IPA 3 SMA Batik 2 Surakarta Tahun Pelajaran 2013/2014 (Application of Guided Inquiry Model on 
The Influence of Inquiry Learning Model on Student's Scientific Attitudes in Ecosystem Topic at MTs. Daarul Hikmah Sei Alim (Islamic Junior High School) Asahan

Coordination System Material to Improve Science Process Skills of Student Class XI IPA 3 SMA Batik 2 Surakarta Lesson Year 2013/2014). Jurnal Pendidikan Biologi, 7( 2): 80 - 93.

[18] Solichah, A. P., Parmin., S. Nurhayati. 2013. Pengembangan Lembar Eksperimen IPA Terpadu Berbasis Inquiry dalam Outdoor Learning pada Tema Ekosistem (development of inquiry based- experiment sheeets of integrated science in outdoor learning of ecosystem topics) . Unnes Science Education Journal, 2(2): $337-343$.

[19] Sutama, I. N., I. B. P. Arnyana, I. B. J. Swasta. 2014. Pengaruh Model Pembelajaran Inkuiri Terhadap Ketrampilan Berpikir Kritis dan Kinerja Ilmiah pada Pelajaran Biologi Kelas XI IPA SMA Negeri 2 Amlapura (Effect of Inquiry Learning Model on Critical Thinking Skill and Scientific Performance on Biology Lesson of Class XI IPA SMA Negeri 2 Amlapura). e-Journal Program Pascasarjana Universitas Pendidikan Ganesha. (online) Volume 4. (htpp ://www.Pasca. undiksha.ac.id/e-journal/ index. php/jurnal).

[20] Widyaningsih, S. Y., Haryono, S. Saputro. 2012. Model MFI dan POGILl Ditinjau dari Aktivitas Belajar dan Kreativitas Siswa Terhadap Prestasi Belajar (Model of MFI and POGILl Viewed from Learning Activities and Student Creativity to Learning Achievement). Jurnal Inkuiri, 1(3): 266 - 275.

\section{AUTHORS' BIOGRAPHY}

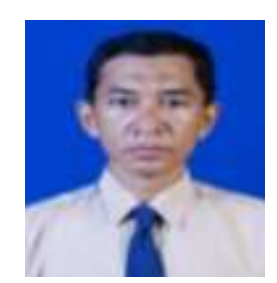

Haji Hamidun Sitorus, S.P., is Biology postgraduate student of UNIMED (State University of Medan), North Sumatera, Indonesia. Postal code 20221. Obtain his Bachelor Degree of agriculture from Agriculture Faculty of Universitas Islam Sumatera Utara (Islamic University of North Sumatera) in Medan.

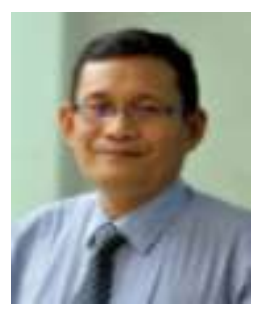

Dr. Hasruddin, M.Pd.,is Head Lecturer in Graduate Program of Biology Education State University of Medan,North Sumatera,Indonesia. Postal Code 20221. Obtain Bachelor Degree of education in IKIP Medan, completing Master of Education in IKIP Malang and completing Doctoral Program at State University of Malang.

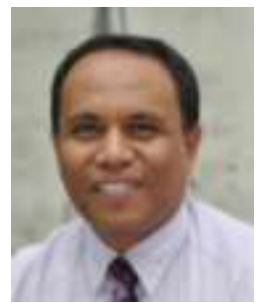

Dr. Syahmi Edi. M.Si., is Head Lecturer in Graduate Program of Biology Education State University of Medan,North Sumatera, Indonesia. Postal Code 20221. Obtained Bachelor degree at Andalas University Padang, completing Master of Science in IPB Bogor and completing Doctoral Program in IPB Bogor.

Citation: Haji Hamidun Sitorus et al. "The Influence of Inquiry Learning Model on Student's Scientific Attitudes in Ecosystem Topic at MTs. Daarul Hikmah Sei Alim (Islamic Junior High School) Asahan" International Journal of Humanities Social Sciences and Education (IJHSSE), vol 4, no. 11, 2017, pp. 170175. doi: http://dx.doi.org/10.20431/2349-0381.0411020.

Copyright: () 2017 Authors. This is an open-access article distributed under the terms of the Creative Commons Attribution License, which permits unrestricted use, distribution, and reproduction in any medium, 